\title{
LAS MILICIAS DE FELIPE V. LA MILITARIZACIÓN DE LA SOCIEDAD CASTELLANA DURANTE LA GUERRA DE SUCESIÓN*
}

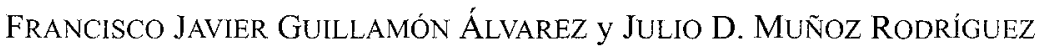 \\ Universidad de Murcia
}

\section{MONARQUÍA, GUERRA Y MILICIAS CASTELLANAS}

Tradicionalmente, se ha reiterado en la historiografía dos imágenes un tanto inexactas sobre las fuerzas militares disponibles por Felipe $V$ en la Guerra de Sucesión. Por un lado, se señalaba el número tan limitado de efectivos nacionales que componía el ejército filipista durante el conflicto sucesorio; una situación que se justificaba en el déficit de tropa y de medios materiales que se arrastraba desde el reinado del último Austria, y que, por sí mismo, reflejaba una de las caras de esa profunda decadencia con la que se identificó a la España de Carlos II. Por otro lado, debido precisamente a ese insuficiente número de efectivos heredado por Felipe V, la contribución militar francesa se percibía como el factor más destacado que permitió el triunfo borbónico en los campos de batalla peninsulares. Sin embargo, tanto el apoyo que Luis XIV proporcionó a su nieto para consolidar sus derechos dinásticos, como el que décadas antes Inglaterra y Holanda prestaron a Carlos II en la defensa de su Monarquía, no fueron los únicos recursos, ni seguramente los más importantes, al alcance de ambos monarcas católicos. La resistencia agónica de los Habsburgo y la posterior victoria del duque de

\footnotetext{
: Este trabajo se enmarca dentro de los proyectos HUM2005-06310 y 03057/PHCS/05, financiados por el Ministerio de Educación y Ciencia y la Fundación Séneca-Agencia Regional de Ciencia y Tecnología, respectivamente. Las abreviaturas empleadas corresponden a: AGS (Archivo General de Simancas): GM (Guerra Moderna), GJ (Gracia y Justicia), E (Estado); AHN (Archivo Histórico Nacional): E (Estado), CS (Consejos Suprimidos); ADMS (Archivo Ducal Medina Sidonia); AHPM (Archivo Histórico Provincial de Murcia); AMM (Archivo Municipal de Murcia): AC (Acta Capitular), AO (Ayuntamiento Ordinario), AE (Ayuntamiento Extraordinario); AMC (Archivo Municipal de Cartagena); AML (Archivo Municipal de Lorca) y AMMu (Archivo Municipal de Mula).
} 
Anjou se debieron, en gran medida, a otros medios más inherentes a la autoridad de los soberanos hispánicos.

Dentro del notable desarrollo que ha tenido la historiografía relativa a las últimas décadas del Seiscientos, la nueva historia militar es quizás la que ofrece un saldo más positivo'. Los trabajos que se han ido publicando parecen haber ya superado ideas que en otro tiempo fueron predominantes sobre la «dependencia» y «agotamiento» militar que habría caracterizado a la Monarquía de Carlos II. Actualmente, no sólo conocemos con cierta profundidad la composición y organización de cada uno de los tres grandes cuerpos que componían el ejército carolino -Flandes, Milanesado y Cataluña ${ }^{2}-$, sino que también comienzan a surgir los primeros análisis globales del poderío militar hispánico de aquel momento. En todos ellos, y en especial en el publicado recientemente por el profesor Storrs, es coincidente la razonable revalorización del papel desempeñado por el ejército austríaco frente a las tropas francesas en su prolongada rivalidad por la hegemonía continental ${ }^{3}$. El ejército carolino, a diferencia de viejos clichés al uso, demostró una cierta capacidad de adaptación ante las enormes exigencias militares que tuvo que soportar la Monarquía Hispánica en ese final de siglo. Así, por ejemplo, se generalizaron prácticas de reclutamiento que ya se habían ensayado en la también difícil coyuntura de 1640 -el sorteo de soldados-; se introdujeron innovaciones técnicas

1. Martínez Ruiz, E. y Pi CORRales, M. DE P., «La investigación en la Historia Militar Moderna: realidades y perspectivas» y GARCÍA HERNÁN, D., «Historiografía y fuentes para el estudio de la guerra y el ejército en la España del Antiguo Régimen», ambos en Revista de Historia Militar, número monográfico (2002) pp. 123-169 y 183-292, respectivamente; también, GARCiA HeRNÁN, E. Y MAFFl, D. (EDS.): Guerra y Sociedad en la Monarquía Hispánica: Política, estrategia y cultura en la Europa Moderna (1500-1700), Madrid, 2006, 2 vols., que recoge las actas del último congreso de historia militar (Madrid, 2005).

2. Para estos tres ejércitos, Riвот GARCía, L., «Milán, plaza de armas de la Monarquía», Investigaciones Históricas, 10 (1990) pp. 203-238; STORRs, CH., «The Army of Lombardy and the Resilience of Spanish Power in Italy in the Reign of Carlos II (1665-1700)», War in History, 4 (1997) pp. 371-397 y 5 (1998) pp. 1-22; Álvarez OSSORIO, A., «De la conservación a la desmembración. Las provincias italianas y la Monarquía de España (1665-1713)», Studia Historica. Historia Moderna, 26 (2004) pp. 191-223; MAFFI, D., «ll potere delle Armi. La monarchia spagnola ed i suoi eserciti (1635-1700): una rivisitazione del mito della decadenza", Rivista Storica Italiana, CXVIII (2006) pp. 388-439; PARKER, G., El ejército de Flandes y el Camino español 1567-1659, Madrid, 1991; Esteban EstríngANA, A., Guerra y finanzas en los Países Bajos Católicos. De Farnesio a Spinola (1592-1630), Madrid, 2002; Espino López, A., Catalunya durante el Reinado de Carlos II. Política y guerra en la frontera catalana, 1679-1697, Barcelona, 1999.

3. Srorrs, CH., The Resilience of the Spanish Monarchy 1665-1700, Oxford, 2006, del que fue un adelanto «La pervivencia de la monarquía española bajo el reinado de Carlos Il (1665-1700)», Manuscrits, 21 (2003) pp. 39-61; una visión más pesimista en EsPINO LÓPEZ, A., «El declinar militar hispánico durante el reinado de Carlos IL", Studia Historica. Historia Moderna, 20 (2002) pp. 173-198. También RiBOT GARCía, L., «Carlos II: el centenario olvidado», Studia Historica. Historia Moderna, 18 (2000) pp. 19-44; De Bernardo ARES, J. M., «El Reinado de Carlos II: la política interior entre 1679-1700» en Actas de las Juntas del Reino de Galicia, Santiago de Compostela, Vol. X, 2002, pp. 37-70; GARCIA CÁRCEL, R., «Fin de siglo, fin de dinastía. Algunas reflexiones», Estudis, 31 (2005) pp. 67-82. La antigua rivalidad entre Habsburgos y Borbones en HARAN, A. Y., Le lys et le Globe. Messianisme dynastique et Rêve Impérial en France aux XVI" et XVIF Siècles, Mayenne, 2000, pp. 309-340. 
-caso del incremento de unidades equipadas con mosquetes y granadas- años antes de que fuesen incorporadas en la poderosa máquina de guerra francesa; $y$, sobre todo, el ejército de Carlos II representó un efectivo instrumento de imposición de nuevas obligaciones contributivas para los súbditos ${ }^{4}$. Aunque es verdad que el último de los Habsburgo poseyó un ejército más pequeño y menos dominante que el de sus antecesores, sin él hubiese sido difícil que el sucesor de Felipe IV legase en 1700 la mayor parte de su vasto patrimonio señorial.

Similares conclusiones podemos extraer del ejército profesional que sostuvo la causa angevina en los primeros años de la centuria ilustrada. En contra de lo que en muchas ocasiones se ha repetido, Felipe $\mathrm{V}$ contó con un contingente militar -entorno a 20.000 hombres en el inicio de su reinado-que fue incrementándose sensiblemente a partir de las reformas acometidas mediante las Reales Ordenanzas de 1704, hasta el punto de que en 1739 sólo el arma de infantería contaba ya con cerca de setenta mil hombres 5 . En la batalla de Almansa (25-IV-1707), probablemente el episodio armado que más efectivos reunió en esta guerra, más de la mitad de los regimientos al mando del duque de Berwick -en concreto, 35- estaban compuestos por soldados procedentes de los distintos reinos que componían la Monarquía, en su mayoría castellanos, junto a un número pequeño de flamencos e italianos -guardias valonas, caballería de Milán-; mientras que el $45 \%$ restante de los combatientes borbónicos -29 regimientos- eran ciertamente unidades francesas enviadas por Luis XIV para fortalecer el ejército de «ambas coronas». Por el contrario, en esa misma batalla, el origen geográfico de los soldados que formaban parte del ejército aliado encabezado por el conde de Galway se situaba casi totalmente fuera de los territorios hispánicos, al venir principalmente de Inglaterra, Portugal y Holanda ${ }^{6}$. A pesar de la contundencia de estos datos, en alguna historiografía ha perdurado una batalla sin apenas soldados españoles y ganada por Felipe $\mathrm{V}$ gracias, fundamentalmente, a las tropas cedidas por su abuelo?

4. El sorteo de soldados en Ruiz IbÁÑez, J. J., Las dos caras de Jano. Monarquía, ciudad e individuo. Murcia, 1588-1648, Murcia, 1995, pp. 321-331, y MuÑoz Rodríguez, J. D., Damus ut des. Los servicios de la ciudad de Murcia a la Corona a finales del siglo XVII, Murcia, 2003, pp. 179-181; asimismo, Rodriguez HernÁndez, A. J., El recluiamiento en Castilla a mediados del siglo XVII (1648-1680), Trabajo de Investigación de Doctorado, Universidad de Valladolid, 2002. La renovación del ejército francés en LYNn, J. A., Giant of the Grand Siècle. The French Army, 1610-1715, Cambridge, 1997.

5. El dato procede de BACAllaR Y SANNA, V. (MARQuÉs DE SAN FeliPE), Comentarios de la guerra de España e historia de su Rey Felipe V, el Animoso, Madrid, 1957 [1725], pp. 25 y 26; sobre estas reformas, Andújar CASTILLO, F., «El ejército de Felipe V. Estrategias y problemas de una reforma» en SERrano, E. (ED.), Felipe Vy su tiempo, Zaragoza, 2004, pp. 661-682.

6. La batalla de Almansa ha sido minuciosamente tratada por SÁNCHEZ MARTíN, J. L., «Almansa, 1707: las lises de la Corona», Researching \& Dragona, 5 (1998) pp. 66-84; 7 (1999) pp. 81-104; 8 (1999) pp. 6691; 12 (2000) pp. 108-113; 14 (2001) pp. 29-41; y 17 (2002), pp. 28-53. También es de interés CerverA TORreıón, J. L., La Batalla de Almansa. 25 de abril de 1707, Valencia, 2000.

7. Sobre esta ayuda militar francesa, KAMEN, H., La Guerra de Sucesión en España, 1700-1715, Barcelona, 1974; y Guillamón Álvarez, F. J. Y MUÑoz Rodríguez, J. D., La formación de un principe de la Ilustración. Selección de la correspondencia privada de Luis XIV a Felipe V durante la Guerra de Sucesión, Murcia, 2006. 
Pero no sólo se ha de relativizar la contribución militar extranjera a partir de los regimientos españoles que integraban un ejército secularmente multinacional. Las fuerzas del rey católico se completaban con tropas de reserva no profesionales cuya relevancia defensiva no ha suscitado hasta ahora la consideración que merecerían. Y es que el verdadero potencial de los monarcas europeos de los siglos modernos no residía únicamente en sus recursos tangibles y visibles, como en sus capacidades de hacer cosas y hacerlas contando con la obediencia de la población. Ese fue el caso de las milicias castellanas, compuestas en vísperas del conflicto sucesorio por los restos de la milicia general -establecida por Felipe II en 1596-8- y las numerosas compañías locales de origen bajomedieval ${ }^{8}$, que participaron en numerosas ocasiones en la protección de diversas fronteras activas: costas mediterráneas, plazas norteafricanas, preferentemente. La falta de soldados veteranos requirió que estas tropas asumieran parte del coste de las urgencias militares que tanto proliferaron a lo largo y ancho de la Monarquía. Aunque las milicias locales habían sido creadas para proteger el entorno más inmediato, la presencia de milicianos asistiendo a su rey fuera de los límites municipales se fue haciendo cada vez más habitual, conforme las elites castellanas se integraban en la política imperial y se revalorizaba esta estrategia como vehículo de ascenso social ${ }^{10}$.

Eran, precisamente, miembros destacados de esas elites los que monopolizaban los principales cargos de las compañías de milicias, ya que para ellos acudir a la guerra al mando de sus vecinos conllevaba un indudable interés privado. A diferencia de las plazas de soldado, ocupadas por un campesinado con posibilidades de promoción social muy limitadas, el ejercicio de los principales puestos de una compañia -capitanía, sobre todo--generaba importantes expectativas de beneficios. De hecho, este tipo

8. Thompson, I. A. A., Guerra y decadencia: Gobierno y administración en la España de los Austrias (1560-1620), Barcelona, 1981, pp. 156-160, y RUIZ IBAÑEZ, J. J., op. cit., 1995, cap. III.3, para su origen; CONTreras Gay, I., «Las milicias pecuniarias en la Corona de Castilla (1650-1715)», Studia Historica. Historia Moderna, 25 (2003) pp. 93-121; STORRS, CH., op. cit., 2006, pp. 39-46, para sus intentos de restauración en 1693. Asimismo, será de especial interés RuIz IBÁÑEZ, J. J. [ED.], Las milicias del Rey de España, siglos XVI-XVII (en prensa), que es fruto de las Segundas Jornadas Internacionales de Historia de las Monarquías Ibéricas (Yecla, 9-11 de noviembre de 2006).

9. STORrs, CH., op. cit., 2006, en general; distintas fronteras en SAnz CAmañes, P., Politica, Hacienda y Milicia en el Aragón de los últimos Austrias entre 1640 y 1680, Zaragoza, 1997; RuIZ IBÁÑEZ, J. J., Felipe II y Cambrai: el consenso del pueblo. La soberanía entre la práctica y la teoría política (15951677), Madrid, 1999; ALONSO ACERo, B., Orán-Mazalquivir, 1589-1639: Una sociedad española en la frontera de Berbería, Madrid, 2000; MAFFI, D., «Milano in guerra. La mobilitazione delle risorse in una provincia della Monarchia, 1640-1659» en RIZZO, M., RUIZ IBÁÑEZ, J. J. Y SABATINI, G. (EDS.): Le Forze del Principe. Recursos, Instrumentos y límites en la práctica del poder soberano en los territorios de la Monarquia hispanica, Cuadernos del Seminario Floridablanca, $n^{\circ}$ 5, Murcia, 2004, T. I, pp. 345-408.

10. ThOMPSON, I. A. A., «Patronato real e integración política en las ciudades castellanas bajo los Austrias» en Fortea PÉrez, J. I. (ED.): Imágenes de la diversidad. El mundo urbano en la Corona de Castilla (S. XVI-XVIII), Santander, 1997, pp. 475-496; asimismo, GuILLAMÓn ÁlvaREZ, F. J. y MuÑOZ RodrigueZ, J. D., «Guerra, lealtad y poder: el origen del municipio castellano de la Ilustración», Estudis. Revista de Història Moderna, 32 (2006) pp. 111-130. 
de servicios de armas pasaron a fundamentar la mayor parte de los prolijos memoriales que se presentaron a la Corona para solicitar cualquier merced real, ya fuesen empleos dependientes de la administración central o municipal, hábitos de órdenes militares $\mathrm{o}$, incluso, títulos nobiliarios ${ }^{11}$. Por esta razón, desde el momento que los súbditos asimilaron con una normalidad no exenta de cierto interés este nuevo discurso de exacción físcal, los monarcas hispánicos dispusieron de un suplemento de fuerzas militares en coyunturas de extrema gravedad. Fue, en gran medida, la reacción de la sociedad castellana -como la de otros reinos hispánicos-ante la amenaza francesa, la que hizo más soportable el peso de la conservación de la Monarquía en las últimas décadas del Seiscientos; y la que contribuyó a reforzar indirectamente el poder soberano y el dominio local de unas elites plenamente subordinadas para entonces a las decisiones de la Corona.

También en la Guerra de Sucesión las compañías de milicias poseyeron una enorme trascendencia. Debido a su experiencia militar previa, no sólo intervendrían incesantemente en el conflicto sucesorio, sino que, especialmente en Castilla, pasaron a ser un instrumento esencial en la formación del ejército borbónico. Muchos de los regimientos que ordenó levantar Felipe $\mathrm{V}$ tenían su origen en milicias locales ${ }^{12}$, lo que facilitó que antiguos milicianos continuaran una carrera al servicio directo del soberano. Asimismo, estas unidades fueron empleadas a menudo en labores auxiliares de defensa, control social o aprovisionamiento de lugares cercanos a un frente militar. Al tiempo que suministraban todo lo necesario para mantener en funcionamiento la maquinaria de guerra, se liberaban tropas profesionales que podían destinarse a otras tareas que exigían mayores habilidades técnicas. En consecuencia, la presencia continua de milicias en la Guerra de Sucesión traducía una extraordinaria capacidad de movilización social en manos de Felipe V, así como un modo de

11. Este ejercicio de justicia distributiva, por ejemplo, en Dominguez ORTIZ, A., «Valoración social de los hábitos de las Órdenes Militares» y ARANDA PÉREZ, F. J., «Caballeros de hábito y oligarquías urbanas», ambos en Las Órdenes Militares en la Península Ibérica, Vol. II: Edad Moderna, Cuenca, 2000, pp. 1157-1176 y 2049-2088, respectivamente; GONZÁLEZ BELTRÁN, J. M., "Constitución y reproducción de una oligarquía urbana. Los Veinticuatros de Jerez de la Frontera en el siglo XVII», Revista de Historia Moderna, 19 (2001) pp. 355-384; HernÁNDEZ BENÍTEZ, M., «Ayuntamientos urbanos, trampolines sociales. Reflexiones sobre las oligarquías locales en la Castilla moderna», Melánges de la Casa de Velázquez, 34-2 (2004) pp. 91-114; para el caso de Murcia, MUÑoz RodriguEz, J. D., op. cit., 2003, esp. cap. 5 , y «Con plausible ejemplo y finisima actividad. La movilización de una ciudad castellana en socorro de la Monarquía: Lorca, 1688», Clavis, 3 (2003) pp. 189-198. Para Francia, Rowlands, G., The Dynastic State and the Army under Louis XIV: Royal Service and Private Interest, 1661-1701, Cambridge, 2002.

12. AndúJar CASTIllo, F., El sonido del dinero. Monarquía, ejército y venalidad en la España del siglo XVIII, Madrid, 2004, pp. 46 y 57; también, DE OÑATE Algueró, P., «Milicias provinciales y Guerra de Sucesión: la Real Cédula de 1704» en La Guerra de Sucesión en España y América, Madrid, 2001, pp. $425-438$. 
actualizarse los antiguos vínculos de lealtad que unían a los súbditos castellanos con su soberano ${ }^{13}$.

El objetivo de estas páginas es demostrar la relevancia que alcanzaron estos cuerpos armados no profesionales en el triunfo borbónico. A través de las milicias castellanas podremos observar el comportamiento y la organización de la sociedad ante una crisis política sin precedentes inmediatos, así como los discursos políticos y los agentes que alentaron y gestionaron el alistamiento de tantos miles de vecinos en armas. La delimitación de nuestra investigación a un espacio concreto de la geografía castellana -el reino de Murcia- permitirá comprobar la intensa militarización a la que fue sometida la población, especialmente la situada en las proximidades a los frentes activos o en las coyunturas de mayor intensidad bélica. Esta militarización de la sociedad castellana e hispánica, en general, no sólo demostraría su utilidad en las primeras décadas del siglo XVIII; también explicaría la naturaleza militar que adquirió la administración territorial borbónica, y estaría en la base del ambicioso programa de proyección exterior llevado a cabo por Felipe $V$ en Italia -territorios perdidos en Utrecht- y en el norte de África - conquista de Orán en 1732-. Por último, la participación de las milicias en la guerra estuvo estrechamente relacionada con la promoción social que experimentaron miembros de las elites locales dentro de la administración dieciochista; su nombramiento como corregidores o alcaldes mayores sería una forma de recompensar sus servicios de armas y su lealtad a la causa angevina.

\section{LOS DISCURSOS DE MOVILIZACIÓN SOCIAL}

La intervención de la sociedad castellana durante la Guerra de Sucesión se debió a diferentes medios de creación de opinión. El empleo de prácticas coercitivas obligó a tomar las armas a un crecido número de vecinos que, de lo contrario, se exponían a penas de cárcel, monetarias o de servicio en frentes de mayor riesgo objetivo como Gibraltar u Orán. La resistencia de los vecinos se equiparaba a un acto de «lesa majestad» o, como afirmarían algunos eclesiásticos radicalmente proborbónicos, a un «pecado mortal» ${ }^{i 4}$. Pero, aún así, junto a estas formas de coacción política y moral, también se trató de convencer al súbdito castellano con argumentos más emotivos que racionales. La intensa persuasión a la que fue sometida el conjunto de la sociedad hispánica se hizo efectiva a través de mecanismos que incidían en sus percepciones visuales, auditivas y hasta táctiles. De ahí que muchos de los discursos políticos que se elaboraron durante la guerra circularan a través de libros, pliegos de cordel, piezas de teatro o periódicos; se plasmaran mediante luminarias, retratos o grabados; y se

13. Cuillamón Álvarez, F. J. y MuÑoz Rodriguez, J. D., «La lealtad castellana en la Guerra de Sucesión. Movilización social y representación del poder en una sociedad en guerra», Revista de Historia Moderna, 24 (2006) pp. 513-536.

14. La afirmación eclesiástica procede del obispo Belluga, pero no fue el único en sostener esta opinión: PÉrez PiCAZO, M. T., La publicistica española en la Guerra de Sucesión, Madrid, 1966, T. II, esp. 5-6. La equiparación a un delito de traición se dio explícitamente en la villa murciana de Mula, AMMu AC 1706 AE 28-VIII-1706. 
transmitieran a través de toques de campana, pregones, rumores o conversaciones. Las consignas e imágenes creadas por ambos partidos dinásticos inundaron la totalidad de los espacios públicos - calle, teatro, reuniones - y privados - casa, tertulias- que eran consustanciales a la vida diaria de principios del siglo XVIII ${ }^{15}$.

En este conflicto de lealtades, el clero logró un protagonismo muy relevante. Su tradicional influencia social se veía incrementada por el cariz religioso que adquirió la guerra, lo que consolidaba su capacidad para interpretar los acontecimientos y mediar ante la población. La Guerra de Sucesión fue considerada como una nueva «cruzada» en la que la lucha contra el protestante desplazó el lugar hasta entonces ocupado por el musulmán en el imaginario colectivo. Por oposición a este «hereje austracista» que definía la publicística proborbónica, se identificó a Felipe $\mathrm{V}$ como el único defensor de la «Religión verdadera». No obstante, esta sustitución en el foco de hostilidad no impedía el mantenimiento de muchos de los recursos que se habían empleado en la defensa frente al peligro berberisco -como era el caso de las milicias locales-e, incluso, la capitalización del ambiente militarista que este enfrentamiento secular había generado entre la población de gran parte de Castilla. La idea del austracista como «hereje» y «sacrílego» conectaba con la imagen del musulmán «infiel» que se había construido desde época medieval ${ }^{16}$, aunque tras el fracaso del Sitio de Viena (1682) el poder otomano perdiese parte de su pujanza en el Mediterráneo occidental.

Por su parte, los austracistas también se hicieron presentes en este combate teológico en el que se convirtió la crisis dinástica, si bien de manera menos efectiva que sus adversarios filipistas. Aunque circularon ciertas imágenes de la profunda religiosidad del archiduque Carlos de Austria, como sucedió con la entrega de su espada a la Virgen de Monserrat ${ }^{17}$, la publicística imperial actuó, en realidad, a remolque del discurso que constantemente se emitía desde el bando borbónico. El arquetipo católico que pretendía encarnar el duque de Anjou fue contrarrestado con la divulgación de sus oscuros antecedentes dinásticos -el origen protestante de la dinastía- y la política regalista

15. Algunos de estos medios culturales en García Cárcel, R., De los elogios a Felipe V, Madrid, 2002; Gulllamón Álvarez, F. J., Muñoz Rodriguez, J. D., Flores Arroyuelo, F, y González Castaño, J., La Guerra de Sucesión en los pliegos de cordel, Murcia, 2005; CAL MARTinez, R., «La Gazeta de Madrid y la Guerra de Sucesión», Cuadernos Dieciochistas, 3 (2002) pp. 33-56; GÓMEZ DE SALAZAR Y Alonso, J., «Gazeta de Murcia de 1706. Notas sobre los orígenes de la prensa murciana», Murgetana, 7 (1957) pp. 36-95; y Morán, M., La imagen del Rey. Felipe V y el Arte, Madrid, 1990.

16. BhrKal, R., Cristianos y musulmanes en la España medieval. El enemigo en el espejo, Madrid, 1984; BUnes IbARRA, M. A. DE, La imagen de los musulmanes y del Norte de África en la España de los siglos XVI y XVII. Los caracteres de una hostilidad, Madrid, 1989; y, más recientemente. Díaz SERrano, A., «Moriscos en todos los mares. Difusión del imaginario morisco en los territorios de la Monarquía Hispánica, siglos XVI-XVII» en Actas del XI Congreso Internacional de la Asociación Española de Americanistas, Murcia, 7-10 de septiembre, 2005 (en prensa).

17. Voltes Bou, P., El Archiduque Carlos de Austria. Rey de los catalanes, Barcelona, 1953, esp. 133; una descripción más minuciosa en el impreso Mercurio veloz de noticias generales publicadas en Zaragoza a 16 de julio de 1706, Zaragoza: Francisco Revilla, 1706. En general, sobre la publicística austracista elaborada en la corte catalana, Alabrus I IGLesias, R. M., Felip Vi l'opinió dels catalans, Lérida, 2001. 
aplicada en Francia por Luis XIV. Al monarca francés se le acusaba de querer acabar con la «libertad de Europa» e imponer su ambicioso proyecto de dominio universal, como se había demostrado al «usurpar» la herencia hispánica mediante un último testamento arrancado con «violencia» a un rey moribundo ${ }^{18}$. De nada sirvieron los mejores derechos que jurídicamente -se decía- asistían a la Casa de Austria ante la fructífera persuasión conseguida por el Rey Sol en la corte madrileña.

Este apreciable contenido religioso favorecía, en consecuencia, el protagonismo del clero en la movilización de una sociedad fuertemente confesionalizada. El poder de la palabra de párrocos, frailes o predicadores poseyó una enorme trascendencia en momentos de extrema necesidad para reclutar, abastecer y alojar tropas, tanto veteranas como procedentes de milicias locales. Los discursos eclesiásticos fueron empleados asiduamente para respaldar y motivar las demandas militares solicitadas por los diversos agentes del rey, de forma que su cumplimiento se equiparase a un deber religioso. El sermón sirvió para transmitir las posiciones más militantes a favor de Felipe $\mathrm{V}$, aprovechando la recepción del lenguaje religioso y los vínculos morales que desencadenaba entre los fieles católicos. Los mismos publicistas proaustríacos reconocían que cada sermón era «una batería pesada que derriba centenares de hombres, casas y pueblos»; y, ciertamente, la Guerra de Sucesión tuvo uno de sus principales escenarios en los terrenos más especulativos de la teología política ${ }^{19}$.

Aunque la mayor parte de los sermones que conocemos para el caso del reino de Murcia fueron impresos con el fin de exaltar destacados acontecimientos militares - victorias y conquistas ${ }^{20}$ - o dinásticos - nacimientos y defunciones de miembros de la familia real ${ }^{21}$-, no hay que olvidar que su importancia como instrumento de movilización social no residía especialmente en estos ejemplos más excepcionales, sino en el resto de los pronunciados diariamente al ritmo de la guerra; sermones estos últimos de los que, lógicamente, carecemos del correspondiente testimonio escrito, pero de los que no sería difícil imaginar su clara intencionalidad política y, sobre todo, su extrema

18. ConzÁlez CRUZ, D., Guerra de religión entre principes católicos. El discurso del cambio dinástico en España y América (1700-1714), Madrid, 2002, esp. pp. 25-36. Los ecos de esa «violencia» empleada con Carlos Il los recoge Bacallar y SAnna, Vicente (MARqués de SAN Felipe), op. cit., 1957, p. 16.

19. Pérez PICAZO, M. T., op. cit. 1966, T. I p. 63. Sobre el uso político del sermón, GonzÁlez Cruz, D., op. cit. 2002; y, en general, Negredo del CerRo, F., «La palabra de Dios al servicio del Rey. La legitimación de la Casa de Austria en los sermones del siglo XVII», Criticón, 84-85 (2002) pp. 295-311.

20. Por ejemplo, LÓPEZ, FR. D., Sermón predicado en acción de gracias: por la restauración de la ciudad de Valencia, al Santo Tribunal de la Inquisición, en el Real Convento de Santo Domingo de Murcia, Murcia: Jaime Mesnier, 1707, para el caso de la conquista de la ciudad de Valencia.

21. Así ocurrió con el fallecimiento del Delfín de Francia, padre de Felipe V, en López ORTEGA, Fr. G., Threno Sacro, Oración fünebre panegírica que en las Reales exequias del Serenisimo Señor Luis de Borbón y Austria, Delfin de Francia, Padre de Nuestro amado dueño Philipo V [... ] en que la Mury Noble y Muy Leal ciudad de Murcia celebró las honras de su Alteza Real en la Iglesia Catedral. Sácala a luz la misma ciudad, y la dedica a su Dueño, y Señor Philipo Quinto, supremo monarca de las Españas, Murcia: Jaime Mesnier, 1711; o del propio Luis XIV, GONZÁLEZ DE SANDOVAL, FR. J., Ecphrasis fúnebre, de las reales exequias, que en la muerte del Señor D. Luis XIV el Grande, Rey de Francia, dispuso la M. N. M. L. y Siete Vezes coronada ciudad de Murcia [...], Murcia: Jayme Mesnier, 1716. 
violencia dialéctica. Bien fuese a través de estas piezas de oratoria sagrada, o a través de otras fórmulas de comunicación social -las cartas pastorales, por ejemplo-, la verdad es que los eclesiásticos $\mathrm{y}$, especialmente, los prelados castellanos más activos como el obispo Belluga, desempeñaron un gran influjo en la elaboración de los discursos políticos que proliferaron por los territorios hispánicos.

La mediación del clero no se limitó, sin embargo, a proporcionar argumentos teológicos a la causa del nieto de Luis XIV. Su implicación en la guerra también abarcó otros aspectos más visibles que contribuyeron a lograr una cierta organización de la sociedad ante los principales acontecimientos de la guerra. La mayor parte de los eclesiásticos murcianos fomentaron las manifestaciones públicas en honor del soberano borbónico, ya fuesen éstas en el interior de los propios templos o en forma de procesiones por las calles principales de las ciudades. La conquista borbónica de Cartagena -17 de noviembre de 1706-o la batalla de Almansa -25 de abril de 1707-, por señalar sólo dos ejemplos bien ilustrativos, fueron noticias comunicadas a las localidades murcianas por el obispo Belluga. En sus cartas a los concejos, el prelado adjuntaba relaciones oficiales impresas e indicaba las disposiciones que debían seguirse para que la población celebrase con diversas demostraciones públicas sendas victorias ${ }^{22}$. Tedeums en las iglesias mayores, repicar de campanas, disparos de cañones y encendido de luminarias solían ser los actos más usuales para conmemorar, con mayor o menor énfasis, cada éxito militar protagonizado por el ejército filipista ${ }^{23}$. En ocasiones, algunos de estos tedeums se oficiaban expresamente ante la presencia de las advocaciones marianas más populares, que solían ser procesionadas para mayor demostración de la intercesión de Dios y la naturaleza religiosa de la guerra. Así, la ciudad de Lorca conmemoró el triunfo de Berwick en la villa de Almansa con una misa de acción de gracias ante su patrona la Virgen del Alcázar; y el obispo Belluga aprovechó el mismo motivo para hacer una procesión general con la milagrosa Virgen de los Dolores -o de las Lágrimas- en la que desfilaría sentado en una silla gestatoria y acompañado por gran número de capellanes y pajes ${ }^{24}$. En definitiva, un intenso bombardeo mediático con el que seguir alimentando el apoyo armado de la población.

22. Nos referimos a Noticia breve de la toma y restauración de la ciudad de Cartagena por las armas de nuestro católico Monarca Felipe Quinto (q. D. g.), comandadas del Sr. Duque de Berwic, día I8 de Noviembre de 1706, Murcia: Vicente Llofriú, 1706; Copia de la relación veridica, que ha venido a esta Ciudad de la Batalla del Campo de Almansa, y Victoria que las Armas de muestro Invicto Monarca Felipe Quinto consiguieron de los Enemigos de nuestra Religión, y de la Corona, el día 25 de Abril de 1707, Murcia: Vicente Llofriú, 1707.

23. AMM AC 1707 AE 27-IV-1707, y AMC AC 1707 27-IV-1707: por la victoria de Almansa, y AC 1708: 20-IV-1709: por la rendición del castillo de Alicante; AML AC 1707 28-IV-1707, 5-VI-1707 y AC 1708 4-VIII-1708: por la victoria de Almansa y la conquista de Zaragoza y Tortosa, respectivamente.

24. AML AC 1707 28-IV-1707; el segundo ejemplo, que fue muy criticado por la ciudad, en AMM AC 1707 10-V-1707, y TORRES FonTes, J. y BosQue CARCELler, R., Epistolario del Cardenal Belluga, Murcia, 1962, pp. 22-25; la justificación de «la mayor procesión que se ha visto en esta tierra» en AHN E 317: Murcia, 3-V-1707: el obispo Belluga a don José Grimaldo. 


\section{LA MILITARIZACIÓN DE LA SOCIEDAD}

Aunque estos discursos de movilización social poseían gran influencia en una sociedad profundamente barroca como era la castellana de principios del siglo XVIII, por sí mismos no explican del todo la amplia militarización lograda por Felipe V. La proximidad de un frente de guerra incrementaba la verosimilitud de las percepciones más radicales que circulaban en torno a las acciones del bando aliado, lo que facilitaba la labor de reclutamiento llevada a cabo por los distintos agentes borbónicos. Ese fue el caso de Murcia, cuyo reino pasó a ser una de las principales fronteras peninsulares con el austracismo, especialmente entre la primavera de 1706 y la de 1707. Durante el tiempo que las tropas aliadas pusieron en peligro la frágil estabilidad que mantenía el ordenamiento borbónico, tanto las elites locales, como el clero y su obispo, consiguieron movilizar casi permanentemente a un sector considerable de la población. Las casi 100 compañías de milicias contabilizadas en las distintas localidades del reino comprendían a más de 5000 vecinos en pie de guerra, es decir, alrededor de un $20 \%$ de los veinticinco mil que entre 1706 y 1707 vivían en territorio murciano (V. ANEXOS I y III) $)^{25}$.

Las elites locales fueron los primeros instrumentos que la Corona activó para concretar los nexos afectivos que unían a los súbditos con el soberano. Su papel como agentes reales se debía no tanto a la relativa debilidad de la administración territorial castellana heredada de los Austrias -centrada principalmente en la figura del corregidor $^{26}$-, como a su experiencia en la transmisión y organización de las demandas serviciales durante la centuria anterior. Asimismo, dominaban los resortes del poder local y, en su gran mayoría, poseían un capital socioeconómico con el que reforzar las disposiciones emitidas desde la corte. Si a estas razones se añade el interés que representaba el servicio directo al monarca, es comprensible que la mayor parte de los puestos de capitanes fuesen ejercidos por regidores o sus familiares más allegados. Incluso, aquellos oligarcas que no obtuvieron en su localidad el ansiado nombramiento de capitán -por rivalidades internas, por exceso de candidatos-, levantaron una compañía de vecinos cuyos gastos eran costeados de forma particular; esta práctica, que había sido frecuente en el siglo anterior, se intensificaría por la necesidad de soldados que

25. La cantidad total de compañías de milicias es dificil de conocer, dadas las múltiples fuentes documentales cuyos datos seria necesario cruzar. No obstante, creemos que ese número es bastante aproximado a la cifra real, así como el cómputo de 50 milicianos por cada una de estas compañias. Para una mayor profundización, MUÑoz RoDriguez, J. D., Felipe V y cien mil murcianos. Movilización social y cambio político en la Corona de Castilla durante la Guerra de Sucesión, tesis doctoral inédita, Universidad de Murcia, 2007.

26. Si bien la figura del corregidor está siendo sometida a revisión historiográfica (por ejemplo: FORTEA PÉREZ, J. I., «Príncipes de la República. Los corregidores de Castilla y la crisis del reino (1590-1665)», Estudis, 32 (2006) pp. 73-110), la creación de otras figuras delegadas en la segunda mitad del siglo XVII, como el superintendente de rentas reales (SÁNCHEZ BELÉN, J. A., «Absolutismo y fiscalidad en Castilla a fines del siglo XVII: el Encabezamiento general del reino (1682-1685)», Espacio, Tiempo y Forma, Serie $I V, 2$ (1989) pp. 175-218), da muestra de su debilidad para asumir la creciente influencia política del monarea. 
persiguió a Felipe V. A este modelo de organización militar se ajusta la mayoría de las compañias de milicias levantadas en el reino de Murcia durante el conflicto sucesorio, muy similar a lo que ocurrió en otras fronteras como Andalucía o Soria ${ }^{27}$.

Si bien queda fuera de los propósitos de estas páginas ofrecer un tratamiento minucioso de cada una de las milicias que recogemos en el ANEXO I, al menos señalaremos los cuatro escenarios que concentraron el empeño armado de estos varios miles de vecinos. La defensa de la capital murciana fue, quizás, el objetivo prioritario de las autoridades regionales, ya que de su resistencia dependió el avance austracista hacia Andalucía. En el verano de 1706 se reclutó a la mayor parte de la población hábil en el manejo de armas, quedando reflejado en las numerosas compañías levantadas en esta ciudad, en su mayoría encabezadas por los regidores y jurados más proborbónicos. La contención de la Cartagena austracista, sublevada el 24 de junio de 1706 , también requirió de la presencia de estas tropas no profesionales; un cordón preventivo compuesto mayoritariamente por milicianos de Murcia, Lorca, Totana, Librilla y Mazarrón se establecería entorno a este puerto mediterráneo. La misma labor de contención se llevó a cabo en el interior del reino debido a las diversas incursiones protagonizadas por el ejército aliado. De hecho, en la villa de Almansa, se dio el 25 de abril de 1707 el primer enfrentamiento entre los ejércitos comandados por Berwick y Galway, cuando prácticamente toda la zona había caído en manos del Archiduque. Como se puede observar por el número de compañías surgidas en estas localidades -Villena, Almansa, Jumilla o Yecla-, la contribución militar de la población alcanzó gran intensidad, como consecuencia de la proximidad del ejército enemigo y de los discursos movilizadores puestos en circulación por elites y clero. Por último, las milicias murcianas fueron empleadas también en la conquista del reino de Valencia, tanto a comienzos de 1706, tras su cambio de lealtad dinástica, como inmediatamente después de la batalla de Almansa.

Siendo trascendental la intervención de las elites locales en la organización militar, el papel del clero como agente del poder monárquico tampoco fue menor. Muchos eclesiásticos participaron directamente en la guerra al mando de tropas, constituyendo el reino de Murcia una de las fronteras donde esta situación adquirió un grado más extremo. El socorro de Alicante en los primeros meses de 1706 proporcionó al obispo Belluga la oportunidad de presentarse ante la opinión pública como un prelado que luchaba por «Dios, el Rey y la Patria» junto a un ejército de más de tres mil milicia$\operatorname{nos}^{28}$. A la defensa de la capital murciana en septiembre de ese año acudieron, incluso,

27. No abundan los trabajos sobre esta movilización de la población castellana; nos han servido como modelos comparativos, Calvo Poyato, J., Guerra de Sucesión en Andalucia, Córdoba, 1982; Contreras GAY, J., «La unión defensiva de los reinos de Andalucía en la Guerra de Sucesión» en La Guerra de Sucesión en España y América, Madrid, 2001, pp. 15-78; Bel Bravo, M. A., Cañada Hornos, M. J., Díaz Hernández, J. M., Moral Troya, A. y Rueda Jándula, I., La Guerra de Sucesión en la Provincia de Jaén desde la perspectiva de la mueva historia cultural, Jaén, 2002; y AGUIRRE MARTiN, C., Los avatares de la Guerra de Sucesión en El Burgo de Osma (1700-1714), Soria, 2000.

28. Al respecto es de especial interés el impreso titulado Célebre pompa, magnifico aparato y festivas demostraciones, con que los muy ilustres señores de la Junta de ambos cabildos Eclesiástico y Secular [...] ha ejecutado por los felices sucesos conseguidos por el Ilustrisimo señor Don Luis Belluga y Moncada [... 
sacerdotes y frailes bajo las órdenes de sus superiores «con hábitos enfaldados, puestas en la cinta espadas y chafarotes, cada uno con un fusil al hombro, cruzados los pechos con las bolsas de las municiones y en la cabeza un sombrero de tres picos con una escarapela de cintas blancas y encarnadas ${ }^{29}$. Esta decidida actuación militar del obispo Belluga y otros religiosos murcianos se manifiesta en la adopción de relevantes empleos militares: el primero fue nombrado virrey y capitán general de Valencia en junio de 1706, al que sumó el título de «capitán general de las tropas», «general»o hasta «virrey» que indistintamente se empleó para referirse a su autoridad dentro del ámbito territorial murciano; por su parte, el inquisidor don José Fernández de Toro, obispo electo de Oviedo, se intituló por las mismas fechas como «general de las tropas del reino» y «comandante de las milicias de la frontera de Villena», cargos todos ellos inexistentes hasta ese momento en la administración político-militar.

El titular de la diócesis de Cartagena fue, ciertamente, una pieza fundamental para convencer a las ciudades y villas de la urgencia de una decidida colaboración con la Corona, en el reclutamiento de hombres aptos para los nuevos regimientos del ejército, así como en el envío de dinero y víveres para su abastecimiento. En junio de 1706, por ejemplo, colaboró en la formación de cuatro regimientos de infantería a partir de las milicias del reino que le habían acompañado en la defensa de la ciudad de Villena y otras localidades manchegas cercanas, cuyas plazas de oficiales se encargaría él mismo de otorgar entre los miembros de las elites locales ${ }^{30}$. Entre ellos se encontraban regidores de Murcia - los coroneles don Gil Francisco Molina de Junterón y don Baltasar Fontes de Albornoz, por ejemplo-, Cartagena -el coronel don Francisco de Montenegro Imperial-, Lorca -el coronel don Diego Antonio Alburquerque Leonés-, Cieza -el coronel don Matías Marín-Blázquez- y Mula -los capitanes don Fernando Dato y don Juan Fernández Capel-, todos ellos individuos que se destacarían en la defensa de los derechos dinásticos de Felipe V.

No obstante, si la intervención del prelado constituye uno de los topoi más conocidos de la Guerra de Sucesión en el levante peninsular, no fue menos decisiva su labor de ideólogo y promotor de los discursos político-religiosos que contenían la propaganda borbónica. Belluga se dirigió a sus diocesanos en numerosas ocasiones, empleando para ello cartas pastorales, sermones y oraciones públicas que tuvieron notable trascendencia incluso más allá del ámbito castellano. Así, por ejemplo, su Carta a los fieles

en el socorro de Alicante, y restauración de las villas de San Juan, Muchamiel, Relleu, Onteniente y los demás de su distrito en este año de 1706, que publicó Pérez Gómez, A., El cardenal Belluga. Pastorales y documentos de su época, Murcia, 1962, pp. 65-72; también, MiÑanA, J. M., La Guerra de Sucesión en Valencia. Edición a cargo de F. J. Pérez y J. M. Estellés, Murcia, 1985, pp. 88-92; Pradells NADAL, J., Del foralismo al ceniralismo. Alicante, 1700-1725, Alicante, 1984, pp. 53-60; y PÉREZ APARICIO, C., «EI conflicte successori: guerra i pau al País Valencià» en Enfrontaments civils: postguerres i reconstruccio$n s$, Lérida, 2005, pp. 55-74. Sobre el mando de tropas por religiosos castellanos, GonzÁLEZ CruZ, D., op. cit., 2002 , esp. pp. 256-263.

29. La referencia la da Domínguez OrTiz, A., Estado y Sociedad en el siglo XVIII español, Barcelona, 1990, p. 43

30. AHN E 504: Madrid, 13-VJ-1706: don José Grimaldo a don Daniel Mahoni. 
de su Diócesis o el Sermón sobre el pretendido milagro de la Virgen de las Lágrimas llegaron a difundirse por los virreinatos americanos e Italia: el primero fue reimpreso en Lima en 1710 por orden del arzobispo don Melchor de Liñán y Cisneros; y el segundo en Nápoles en vísperas de la conquista de este territorio por las tropas imperiales ${ }^{31}$. La tolerancia social con la que la población asumió las continuas demandas militares fue lograda, en parte, a estas muestras de propaganda dinástica que tanto se valían de las devociones católicas para justificar opciones políticas concretas.

\section{LA GESTIÓN DE LOS RECURSOS PARA LA GUERRA}

Además de las elites locales y del obispo Belluga, la creciente coerción política provino a partir de otras vías más dependientes del sistema de gobierno de la Corona. La necesidad de conseguir mayor eficacia en la gestión de los recursos movilizados -como eran las milicias locales- fue lo que llevó a establecer una nueva red de agentes reales que, en realidad, constituía una estructura político-militar de nueva planta y con ciertas influencias francesas, yuxtapuesta a los resortes administrativos ya existentes. En muchas ocasiones se trataba de un desplazamiento de las instancias civiles por estas otras de carácter militar, de forma similar a lo que sucedería con la administración borbónica que se impondría en los territorios de la Corona de Aragón después de la supresión de sus fueros ${ }^{32}$. En el reino de Murcia, esta nueva estructura político-militar se tradujo en la presencia de dos nuevos gobernadores militares -en Cartagena y la capital-, otros cuatro cargos con funciones de comandante -dos en las ciudades anteriores y otros dos en Lorca y Villena-, además de dos empleos de comisario real de guerra. Casi todos los individuos que ocuparon estos nuevos cargos pertenecían al ejército, o habían desempeñado con anterioridad tareas de gestión fiscal dentro del sistema de superintendencias, lo que implicaba en ambos casos una experiencia en el servicio al monarca.

El gobernador militar y el teniente de Rey de Cartagena fueron creados tras la conquista de esta ciudad por las tropas del duque de Berwick en noviembre de 1706. El primero, para el que sería nombrado el coronel de origen irlandés don Daniel Mahoni ${ }^{33}$, contaba con el antecedente del gobernador político y militar que se establecería en

31. Billuga y MonCAda, L. A., Sermón que el obispo de Cartagena, [...] se celebró a Marría Santísima de los Dolores en su santisima imagen de las lágrimas, en acción de gracias por el nacimiento de nuestro Serenisimo Principe el Señor don Luis Fernando, Principe de Asturias, dedicalo a la Magestad Católica de el Rey N. S. don Felipe Quinto, el Magnánimo, Rey de las Españas, Murcia, Vicente Llofriu, 18 de setiembre de 1707; y Carta del llmo. Sr. D. Luis Belluga [...] escrita a los fieles de su Obispado: principalmente a la gente sencilla, previniéndoles del riesgo de dar crédito a una falsa doctrina y error, que en conversaciones privadas y hasta en el confesionario en esta Ciudad y en algunos lugares de la Diocesi se ha procurado sembrar, Murcia: s.i, 1706.

32. GMÉnez LÓPEz, E., Gobernar con una misma Ley. Sobre la Nueva Planta Borbónica en Valencia, Alicante, 1999, esp. pp. 13-47.

33. AMC AC 1707 AO 28-II-1707: bienvenida al coronel Mahoni; el titulo era del dí 9 del mismo mes. 
Cartagena, como en otros puertos mediterráneos, a principios de la década de $1650^{34}$. El teniente de Rey, por su parte, redefinía el antiguo puesto de castellano del castillo de la ciudad, pero otorgándole mayores atribuciones gubernativas. Este empleo fue desempeñado por don Patricio Misset, capitán de un regimiento de irlandeses del ejército francés -luego ascendido a coronel y gobernador de Alicante-, y llevaba aparejado cubrir las ausencias del gobernador militar de Cartagena ${ }^{35}$. El teniente de Rey Misset, que indistintamente asumía el título de comandante ${ }^{36}$, consiguió erigirse en uno de los más destacados representantes de la Corona en Cartagena en ausencia de su gobernador-que proseguía con sus tropas el avance por territorio valenciano-, y especialmente en detrimento de las competencias que eran propias al también nuevo corregidor de la ciudad, don Pablo Ayuso y Garbia ${ }^{37}$. Durante algún tiempo fueron frecuentes los conflictos de jurisdicción entre los poderosos representantes militares y la nueva administración civil que se situó en el la ciudad portuaria.

Esta misma intención de eficacia subyacía en los cargos de gobernador militar de Murcia y en los de comandantes de las ciudades de Lorca y Villena. En el primer caso, fue el propio coronel Mahoni el que solicitó a Grimaldo en 1707 la creación de este nuevo empleo, del que dependerían inicialmente las tropas profesionales y milicianas acuarteladas en las proximidades de la capita ${ }^{38}$. Sin embargo, sus funciones militares fueron ampliándose en una ciudad muy cercana al frente de guerra, donde el control de la población constituía un objetivo primordial. El gobierno militar de Murcia sería ejercido, en un primer momento, por el mariscal de campo don Tomás Vicentelo y Toledo, hermano del II marqués de Brenes, auxiliado en las tareas de comandancia por el antiguo sargento mayor de milicias del reino, otro de los empleos que verían redefinido su título y competencias durante la Guerra de Sucesión. De este modo, sería el coronel don Gerónimo Miño y Valterra, que se había encargado por orden del obispo Belluga de la antigua sargentía a su vuelta de la defensa de las ciudades de Villena y Alicante, el que pasó a ocupar la nueva comandancia militar de la capital murciana ${ }^{30}$.

Por su parte, en la ciudad de Lorca, con el propósito de fiscalizar los amplios recursos frumentarios de la segunda ciudad del reino de Murcia y de vigilar el paso

34. Sobre esta figura, MUÑoz RodrigueZ, J. D., «Consenso e imposición en la conservación de la Monarquía. La práctica política en un territorio de la periferia castellana: el reino de Murcia (1682-1700)», Hispania, 215 (2003) pp. 969-994.

35. AHN E 463: Madrid, 5-I-1708: despacho del duque de San Juan a don José Grimaldo. La participación de tropas irlandesas en Borreguero BELTRÁN, C., «Soldados irlandeses en el ejército español del siglo XVIH» en VILlar GarCiA, M. B. (ED.): La emigración irlandesa en el siglo XVIII, Málaga, 2000, pp. 103-126.

36. AHN E 463: Cartagena, 31-X-1707: don Patricio Misset a don José Grimaldo.

37. AHN E 504: Cartagena, 5-IX-1707: don Patricio Misset a don José Grimaldo, por la resistencia del corregidor a pagar los 400 doblones a que asciende el sustento de los prisioneros que hay en el castillo.

38. AHN E 287: Carcagente, 14-XI-1707: el coronel Mahoni a don José Grimaldo.

39. AHN E 504: Murcia, 16-VIIl-1707: don Gerónimo Miño a don José Grimaldo, donde señala sus servicios. 
natural hacia Andalucia ${ }^{40}$, vital en la estrategia de la guerra, se dispondría desde 1706 del «cabo y comandante de Lorca, su castillo y fronteras», lo que carecía de un antecedente inmediato más allá del ofício de alcaide del castillo que estaba en manos de los marqueses de los Vélez y que ejercían mediante tenientes desde época bajomedieval. No obstante, conforme el frente de guerra se adentró en el reino de Valencia este puesto militar perdió importancia hasta quedar durante algún tiempo en posesión de regidores de la ciudad ${ }^{41}$. Por último, el comandante militar de la ciudad de Villena se situaba, igualmente, en otro espacio de importancia estratégica, cercano a la llanura manchega y a la vía de comunicación con el reino de Valencia ${ }^{42}$. Una posición estratégica entre los territorios de Castilla y Aragón que se demostraría al producirse allí la crucial batalla de Almansa.

Estructura político-militar en el reino de Murcia (1706-7)

\begin{tabular}{|l|l|c|l|l|}
\hline Localidad & Nuevo cargo & Año & Antecedente inmediato & \multicolumn{1}{|c|}{ Persona encargada } \\
\hline Cartagena & $\begin{array}{l}\text { Gobernador } \\
\text { militar }\end{array}$ & 1706 & $\begin{array}{l}\text { Gobernador de lo } \\
\text { político y Militar }\end{array}$ & $\begin{array}{l}\text { Coronel don Daniel Mahoni, } \\
\text { futuro conde de Mahoi }\end{array}$ \\
\hline Cartagena & $\begin{array}{l}\text { Teniente de Rey/ } \\
\text { comandante }\end{array}$ & 1706 & Castellano del castillo & Capitán don Patricio Misset \\
\hline Murcia & $\begin{array}{l}\text { Gobernador } \\
\text { militar }\end{array}$ & 1707 & inexistente & Mariscal don Tomás Vicentelo \\
\hline Murcia & Comandante & 1707 & $\begin{array}{l}\text { Sargento mayor de } \\
\text { milicias de la ciudad y } \\
\text { el reino }\end{array}$ & $\begin{array}{l}\text { Coronel don Gerónimo Miño } \\
\text { y Valterra }\end{array}$ \\
\hline Lorca & Comandante & 1706 & inexistente & $\begin{array}{l}\text { Teniente Coronel don Pedro } \\
\text { de Castro y Cárdenas y el } \\
\text { regidor don Juan Alfonso } \\
\text { Alburquerque Marín }\end{array}$ \\
\hline Villena & Comandante & 1706 & inexistente & $\begin{array}{l}\text { don Agustín de Vargas } \\
\text { Machuca y el brigadier } \\
\text { don Domingo Robinier } \\
\text { («gobernador-comandante) })\end{array}$ \\
\hline Murcia & Comisario real & 1706 & inexistente & $\begin{array}{l}\text { don Eugenio de Yepes, regidor } \\
\text { de Murcia }\end{array}$ \\
\hline Cartagena & Comisario real & 1707 & inexistente & $\begin{array}{l}\text { don Pedro Antonio Tacón y } \\
\text { Cárdenas, regidor de Cartagena }\end{array}$ \\
\hline
\end{tabular}

FUENTE: Diversa documentación consultada.

40. AML AC 1702 AO 30-VIII-1702: entrega de 160 fanegas de trigo; AC 1707 AO 6-111-1707; trigo y cebada para socorrer la plaza de Orán por orden del Obispo Belluga; o AC 1709 AO 23-II-1709: Memoria de las partidas de trigo que han entregado diferentes particulares.

41. AHN E 504: Campo de Murcia, 28-VII-1706: el capitán don Pedro de Castro y Cárdenas, comandante de Lorca, a don José Grimaldo, solicitando se le ascienda a brigadier. E1 3 de octubre Belluga nombraba con parecidos títulos al regidor don Juan Alfonso Alburquerque Marín y Leonés, AML AC 1706 AO $6-\mathrm{X}-1706$.

42. AHN E 504: Alicante, 24-VII-1706: el coronel Mahoni al obispo Belluga. 
Las reformas emprendidas por Felipe $\mathrm{V}$ también conllevaría la creación de nuevas instancias en la administración territorial del ejército. Como mimesis a los órganos inspectores dependientes de la secretaría de Guerra, en las ciudades de frontera donde se concentraban gran cantidad de tropas se estableció el empleo de comisario real de guerra, título que puede prestarse a confusión con los cometidos militares que habían desempeñado tradicionalmente algunos regidores en los concejos castellanos ${ }^{43}$. Sin embargo, los comisarios de guerra dependían jerárquicamente de la administración de la Corona y eran los encargados de las labores plenamente comisariales de control, intendencia y reclutamiento de las tropas acuarteladas en las distintas poblaciones. $\mathrm{Su}$ aparición en el reino de Murcia, por ejemplo, fue simultánea al levantamiento en 1706 de cuatro regimientos de infantería formados por orden del obispo Belluga a partir de las milicias del reino. La plaza de comisario de guerra fue encomendada al regidor de la capital y hábito de Santiago don Eugenio de Yepes y Rojas ${ }^{44}$, el cual se convertiría en el más activo brazo ejecutor que, en el campo de la gestión militar, tendría el poderoso prelado cartaginense ${ }^{45}$.

Posteriormente, la presencia de numerosas tropas en la recién conquistada Cartagena obligó a nombrar otro comisario en este puerto mediterráneo, lo que se hizo en la persona del también regidor cartagenero don Pedro Antonio Tacón y Cárdenas, hijo de don Domingo Antonio Tacón, veedor y contador de armadas y fronteras ${ }^{46}$. La ambigüedad jurisdiccional de esta figura administrativa, derivada de la necesidad coyuntural con la que surgió, sería el germen de numerosos conflictos jurisdiccionales con los representantes de la antigua administración monárquica, en especial, con los diferentes corregidores de las ciudades del reino. Tan sólo la gestión económica del ejército estaría fuera de las competencias de los comisarios reales, ya que recaería en el nuevo tesorero de guerra, dependiente de otro superior para todo el ámbito peninsular (tesorero mayor de guerra $)^{47}$. Este empleo, desempeñado por don Antonio Vallejo y Medrano, antiguo contador de rentas reales de la superintendencia, completaría la nueva estructura político-militar implantada por Felipe $\mathrm{V}$ para movilizar y controlar una sociedad en guerra.

43. Por ejemplo, en Murcia: RUIZ IBÁÑ̃z, J. J., op. cit., 1995, pp. 227-229.

44. AHN E 504: don José Grimaldo al obispo Belluga: Madrid, 13-VI-1706, donde se le señala un sueldo de 150 escudos y se le promete una plaza de corregidor; anteriormente había desempeñado la administración de las rentas provinciales.

45. AHN E 504: Cartagena, 28-X1-1707: el obispo Belluga a don José Grimaldo.

46. AGS E L458: Madrid, 12-I-1707; y AHPM 6007: Cartagena, 18-V-1710: poder de doña Gerónima de Cárdenas. Existió una larga tradición de los principales linajes cartageneros a ocupar los cargos militares alli existentes; al respecto, MONTOJO MONTOJO, V., «Matrimonio y patrimonio en la Oligarquía Cartagenera (siglos XVI-XVII)» en CHACÓN JIMÉNEZ, F., HERNÁNDEZ FRANCO, J. Y PEÑAFIEL RAMÓN, A. (EDits): Familia, grupos sociales y Mujer en España, Murcia, 1991, pp. 49-95.

47. AHN E 504: Murcia, 16-VIII-1707: el obispo Belluga a don José Grimaldo. Sobre esta figura, DubET, A., «Administrar los gastos de guerra: Juan Orry y las primeras reformas de Felipe V (1703-1705)» en Guimerá, A. y Peralta, V. (COORds.): El Equilibrio de los Imperios: De Utrecht a Trafalgar, Madrid, 2005, pp. 1269-1287. 


\section{EL PRECIO DE LA LEALTAD BORBÓNICA}

La guerra siempre ha servido para recompensar a aliados y castigar a quienes han mantenido una posición equívoca o contraria a la sostenida por el triunfador. La Guerra de Sucesión no escaparía de esta constante histórica, siendo como fue, además, un conflicto civil que enfrentó a vecinos de los distintos reinos hispánicos por defender opciones dinásticas contrapuestas. Apoyar militarmente la opción borbónica conllevó que se cumplieran las expectativas de mercedes que buena parte de las elites castellanas esperaban de su colaboración armada, muchas veces en el frente de batalla, pero otras muchas por fomentar tan sólo la legitimidad dinástica y la contribución fiscal de la población ${ }^{48}$. En este sentido, el reinado de Felipe $\mathrm{V}$ continuó e, incluso, intensificó una evolución ascendente de la liberalidad regia que se había iniciado aproximadamente a mediados del Seiscientos, simultáneamente al debilitamiento de la hegemonía continental de los Habsburgo. El cambio inmóvil que, en términos nobiliarios, se experimentó en la sociedad castellana durante época moderna tenía una de sus causas en la creciente colaboración militar que los poderosos locales establecieron con la Monarquía ${ }^{49}$.

En el reino de Murcia, la concreción de la gracia real casi siempre contó con la mediación del obispo Belluga, quien su férrea defensa del partido de las lises le permitió convertirse en el agente real con más poder en el sureste castellano y en el árbitro de la difícil posguerra. Los órganos cortesanos le consultaban sobre la idoneidad de las mercedes solicitadas al monarca y consideraban las propuestas realizadas por el prelado para retribuir el apoyo social prestado durante la guerra. Su objetivo de premiar lealtades de las elites locales fue acompañado de un especial cuidado para que las nuevos atributos simbólicos -hábitos o títulos nobiliarios- no supusieran importantes fracturas en el equilibrio del poder local. De este modo, amparó el reconocimiento de individuos que se habían destacado por sus servicios de armas al frente de milicias, como ocurrió, por ejemplo, con don Fernando Dato, don Alonso López García o don Matías Marín-Blázquez, regidores de Mula, Cehegín y Cieza que obtuvieron un hábito de orden militar cada uno ${ }^{50}$; pero, asimismo, no facilitó concesiones -la del título nobiliario de don Francisco Montenegro, regidor de Cartagena ${ }^{51}$ - que podían fortalecer determinados linajes frente a otros.

El mando de una compañía de milicias también permitió iniciar carreras en la administración borbónica, cuya capacidad de absorción profesional creció tras la implanta-

48. Por ejemplo, GonZÁlez Beltrán, J. M., «Constitución y reproducción de una oligarquía urbana. Los Veinticuatros de Jerez de la Frontera en el siglo XVII», Revista de Historia Moderna, 19 (2001) pp. 355384; ANDÚIAR CASTILLO, F., «Servicios para la guerra, mercedes para las oligarquías. Las recompensas de la Guerra de Sucesión en Andalucía) en DE BERnardo Ares, J. M. (ED.): Sucesión de la Monarquía Hispánica, vol. I (en prensa), a quien agradecemos su amabilidad por facilitarnos una copia.

49. La expresión la hemos tomado de SORIA MESA, E., El cambio inmóvil. Transformaciones y permanencias en una élite de poder (Córdoba, siglos XVI-XIX), Córdoba, 2000, asimismo, remitimos a su reciente libro titulado La nobleza en la España moderna, cambio y continuidad, Madrid, 2007.

50. AHN E 287: Cartagena, 1-XI-1707: el obispo Belluga a don José Grimaldo; E 409: Bullas, 14-XII-1711: los mismos; y E 409: Murcia, 17-II-1711, respectivamente.

51. AHN E 409: Cartagena, 9-XI-1711: don Francisco José de Montenegro a don José Grimaldo. 
ción de las nuevas instituciones de gobierno en los territorios de la Corona de Aragón. Después de la guerra, no sería extraño que destacados capitanes de milicias se incorporasen como oidores, corregidores o alcaldes mayores ${ }^{52}$, siendo el caso, entre tantos muchos naturales del reino de Murcia, de don Juan Fernández de Cáceres ${ }^{53}$, don Luis Antonio de Mergelina y Mota $^{54}$, don Gerónimo de Zarandona ${ }^{55}$, don Manuel Valcárcel ${ }^{56}$ y Velasco, don Diego Alejandro Portocarrero ${ }^{57}$ o don José Manuel Piquinotti, conde de Villaleal ${ }^{58}$. A todos ellos, sus servicios de armas les sirvieron para conseguir una posición remunerable ante el soberano que consolidase su capital social.

La militarización de la sociedad castellana durante la Guerra de Sucesión se obtuvo, en consecuencia, a partir del empleo masivo de las milicias locales, una vía que había sido usual en las últimas décadas del siglo XVII ante la amenaza francesa en el Mediterráneo y berberisca en las plazas norteafricanas. Para su movilización, la Corona contó con la colaboración de gran parte de las elites locales y el clero, que se volcaron en la circulación de discursos político-religiosos que alentaran la participación de la población en la defensa armada. Este apoyo militar desde la misma base social castellana paliaba, en parte, la falta de tropas de Felipe $\mathrm{V}$ y, sobre todo, construía un liderazgo político fuertemente interrelacionado con la población. Probablemente a la militarización de la sociedad hispánica de principios del siglo XVIII habría que atribuir la tolerancia social con la que se asumieron los cambios políticos que introduciría el reformismo borbónico.

52. Mblas Ribalta, P., Los magistrados de la Ilustración, Madrid, 2000, y Gómez-Rivero, R., El Ministerio de Justicia en España (1714-1812), Madrid, 1999, donde se recoge la evolución de muchos de los individuos que compusieron la nueva elite política borbónica.

53. Este lorquino fue corregidor de Villena durante la batalla de Almansa, en donde nombró por su teniente a su hermano don Andrés, capitán de una milicia de su ciudad natal; pasó a Valencia como juez de confiscaciones (1710), para luego ir como alcalde del crimen (1715) y oidor (1726) en la Chancillería de Granada, hasta terminar como alcalde de casa y corte (1732-2739); AGS GM 1958: Memorial de servicios de don Andrés Fernández de Cáceres.

54. De regidor de Villena había pasado a corregidor de Carrión y Sahagún (1697), San Clemente (1708), Córdoba (1713), intendente de Salamanca, corregidor de Valencia y, por último, intendente de los reinos de Valencia y Murcia (1718); al respecto, Giménez López, E., Militares en Valencia (1707-1808). Los instrumentos del poder borbónico entre la Nueva Planta y la crisis del Antiguo Régimen, Alicante, 1990, pp. $161-163$.

55. Era regidor de Murcia, de donde pasó como comandante del castillo de Jumilla por nombramiento de Belluga; propuesto para los corregimientos de Chinchilla y Écija (1714), pasó a ostentar el de Cáceres (1715); AGS GJ 133: Madrid, 11-XI1-1714: consulta, y AHN CS 13604: Madrid, 30-IV-1714: consulta.

56. Había sido capitán en la conquista de Valencia y en Orán y fue propuesto para los corregimientos de Teruel (1714) y Cácares (1715), actuando posteriormente como abogado ante los reales consejos; uno de los asuntos que llevó fue en 1724 la constitución de la Universidad de Santiago de Chile con el título de San Felipe; AGS GJ 133: consultas: Madrid, 11-XII-1714, y AHN E 287: Cartagena, 1-XI-1707: consulta.

57. Regidor de Murcia, se destacó en la organización de las milicias de la capital; fue propuesto para los corregimientos de Calatayud (1714) y las Cinco Villas de Aragón (1715); AGS GJ 133: Madrid, 24-I1715: consulta, y AHN CS 13604: Madrid, 19-V-1721: consulta.

58. Regidor de Murcia, también se destacó en la organización de sus milicias, pasando a la conquista de Valencia con el obispo Belluga; fue propuesto para el corregimiento de Huesca (1715); AGS GJ 133: Madrid, 24-I-1715: consulta. 


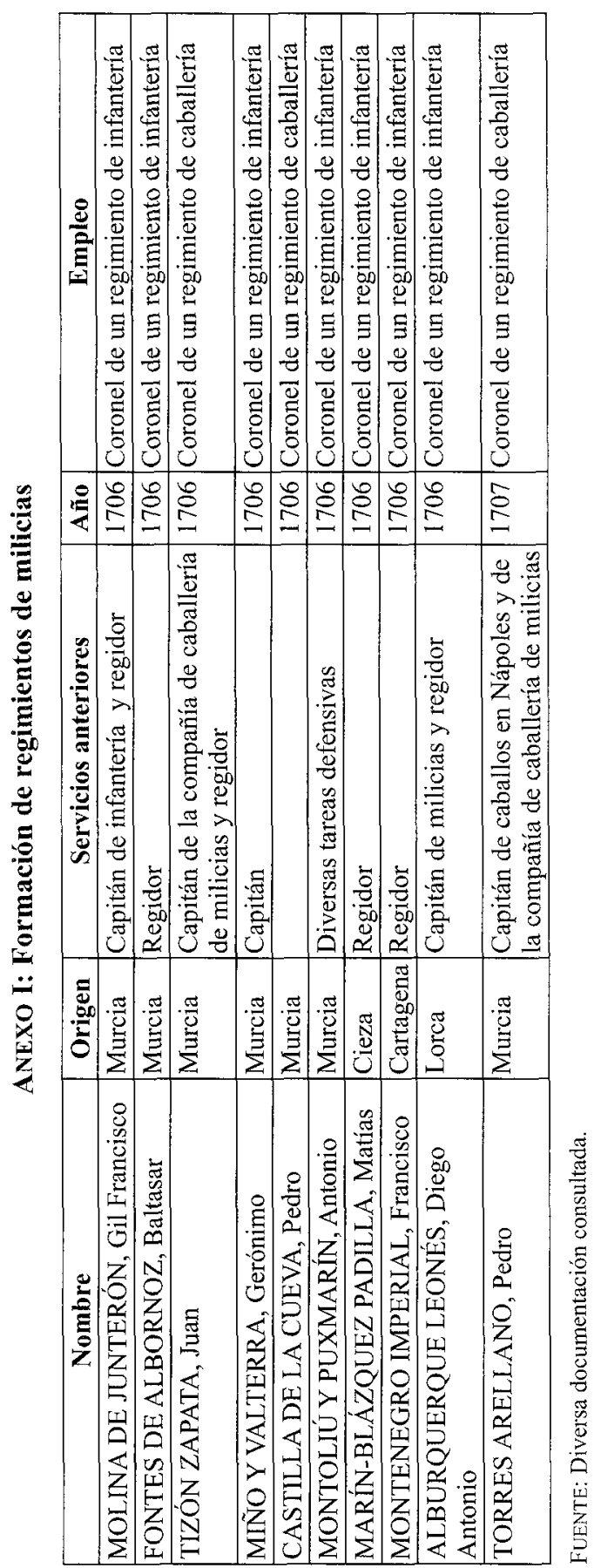




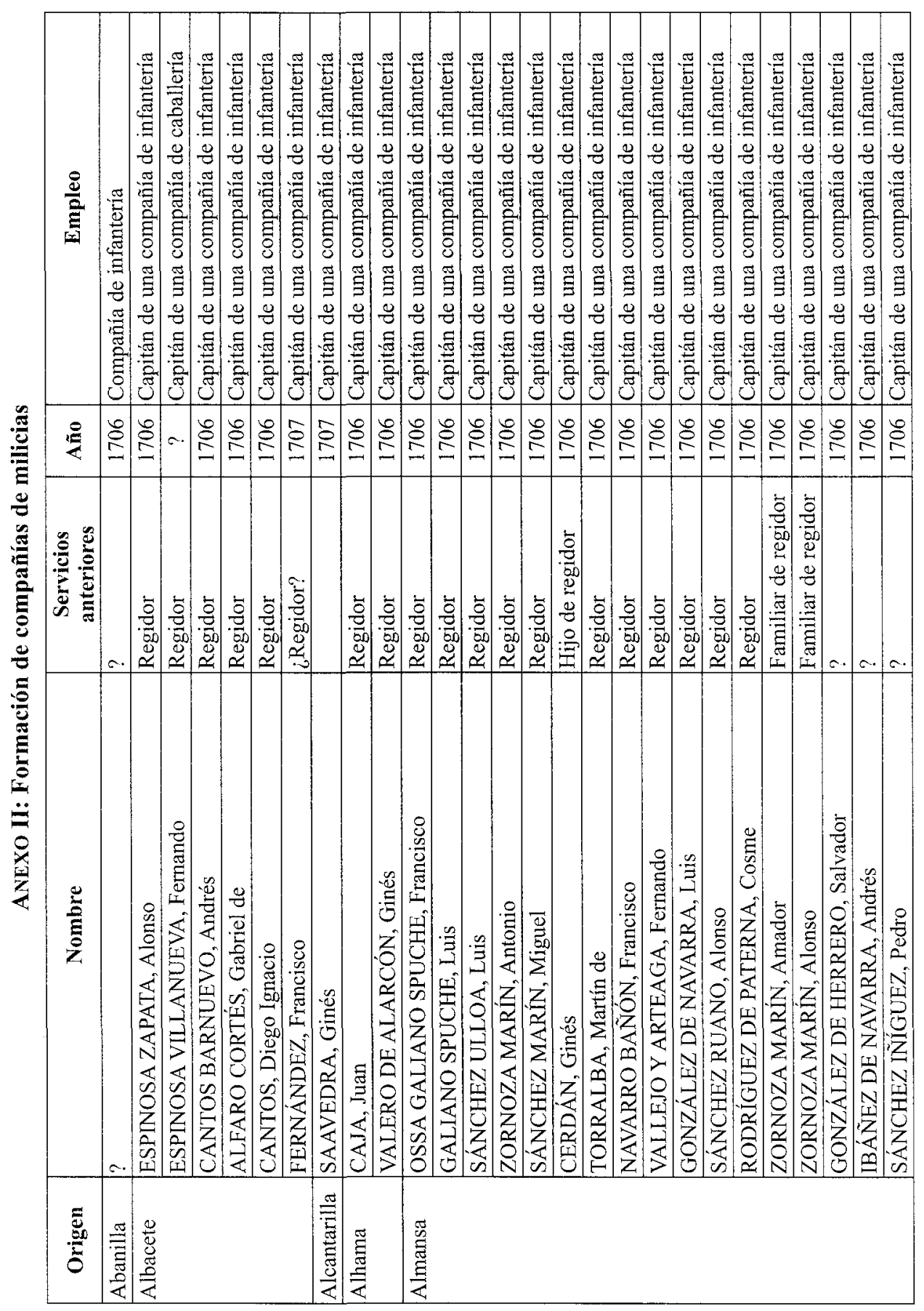




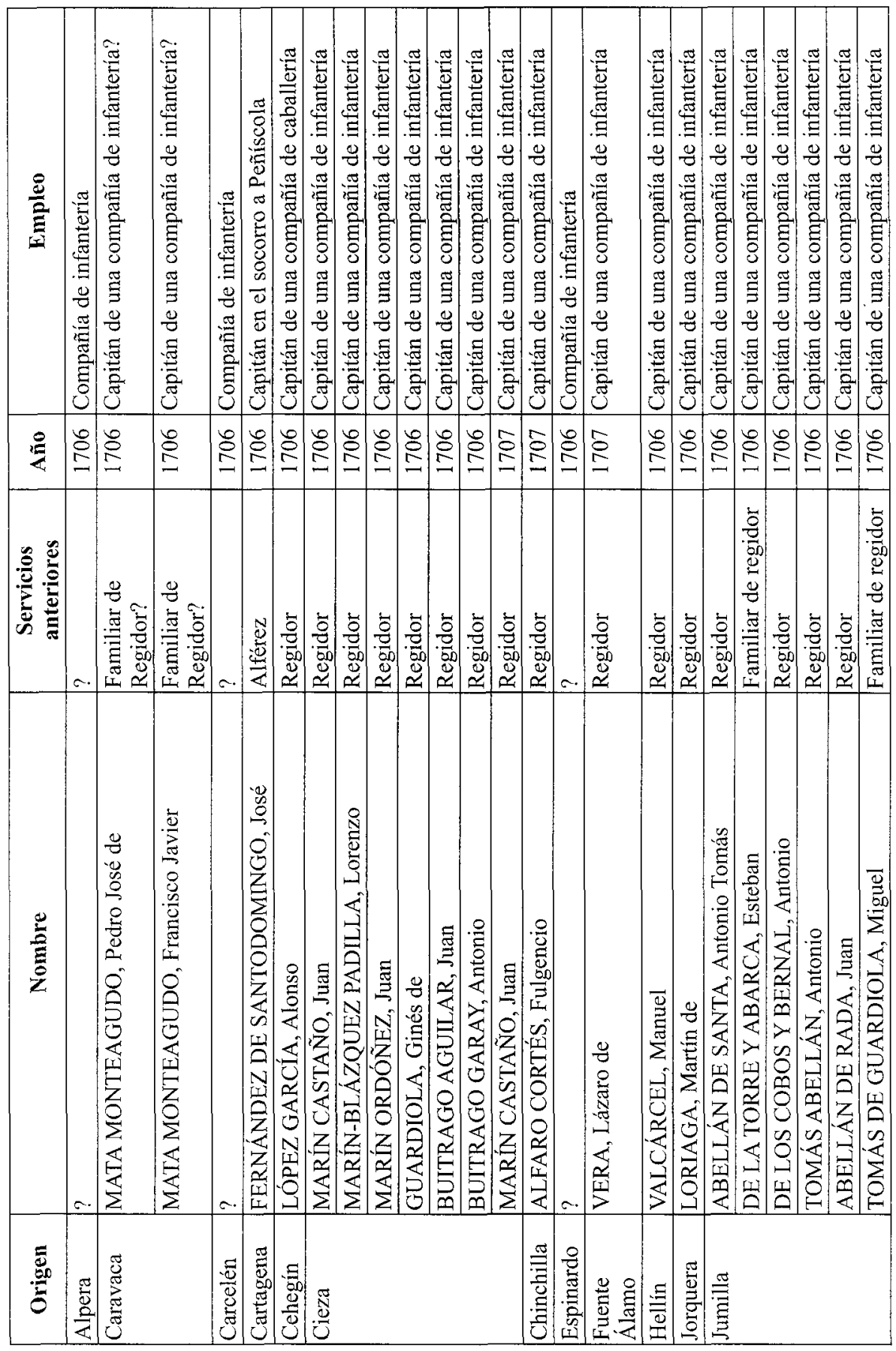




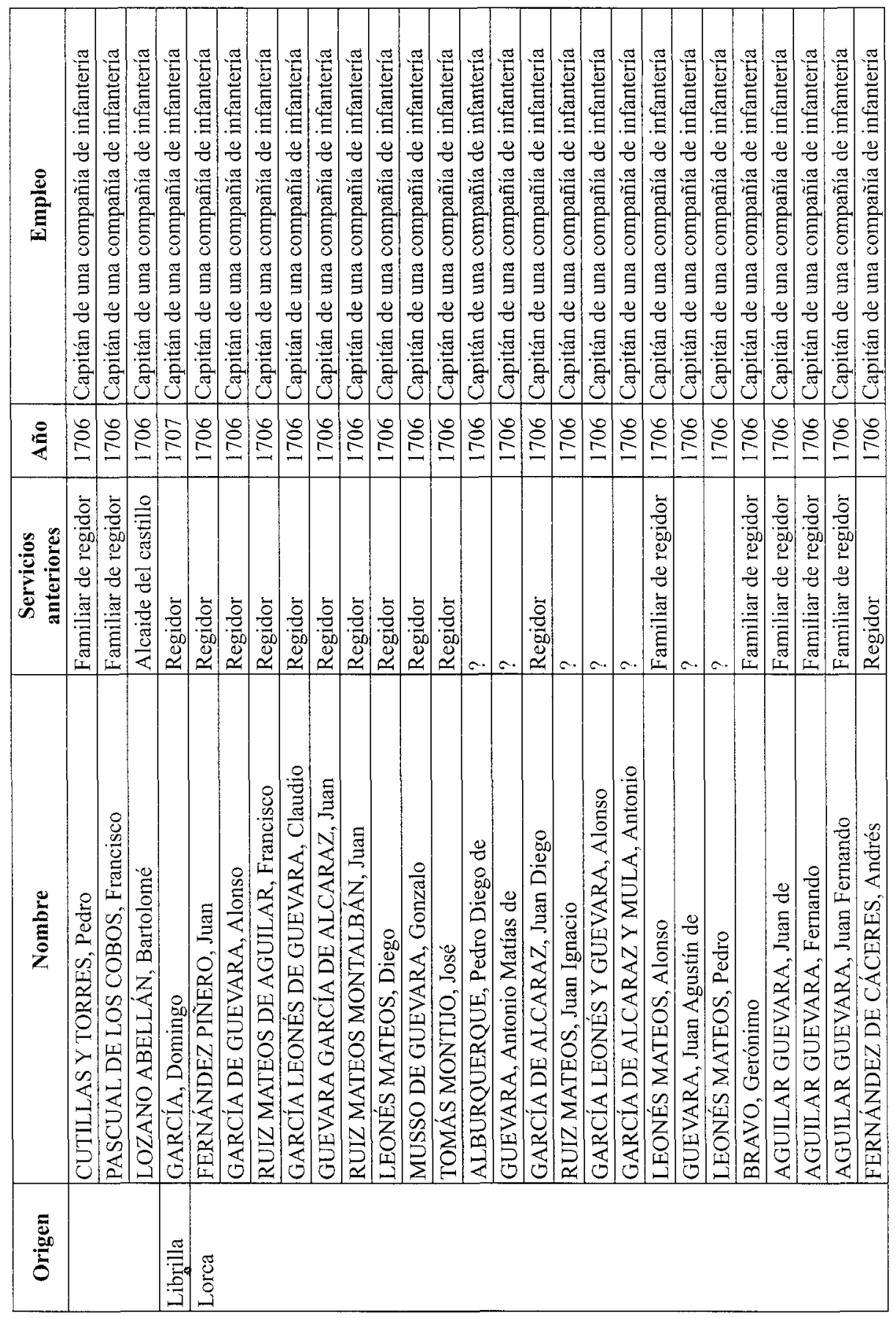




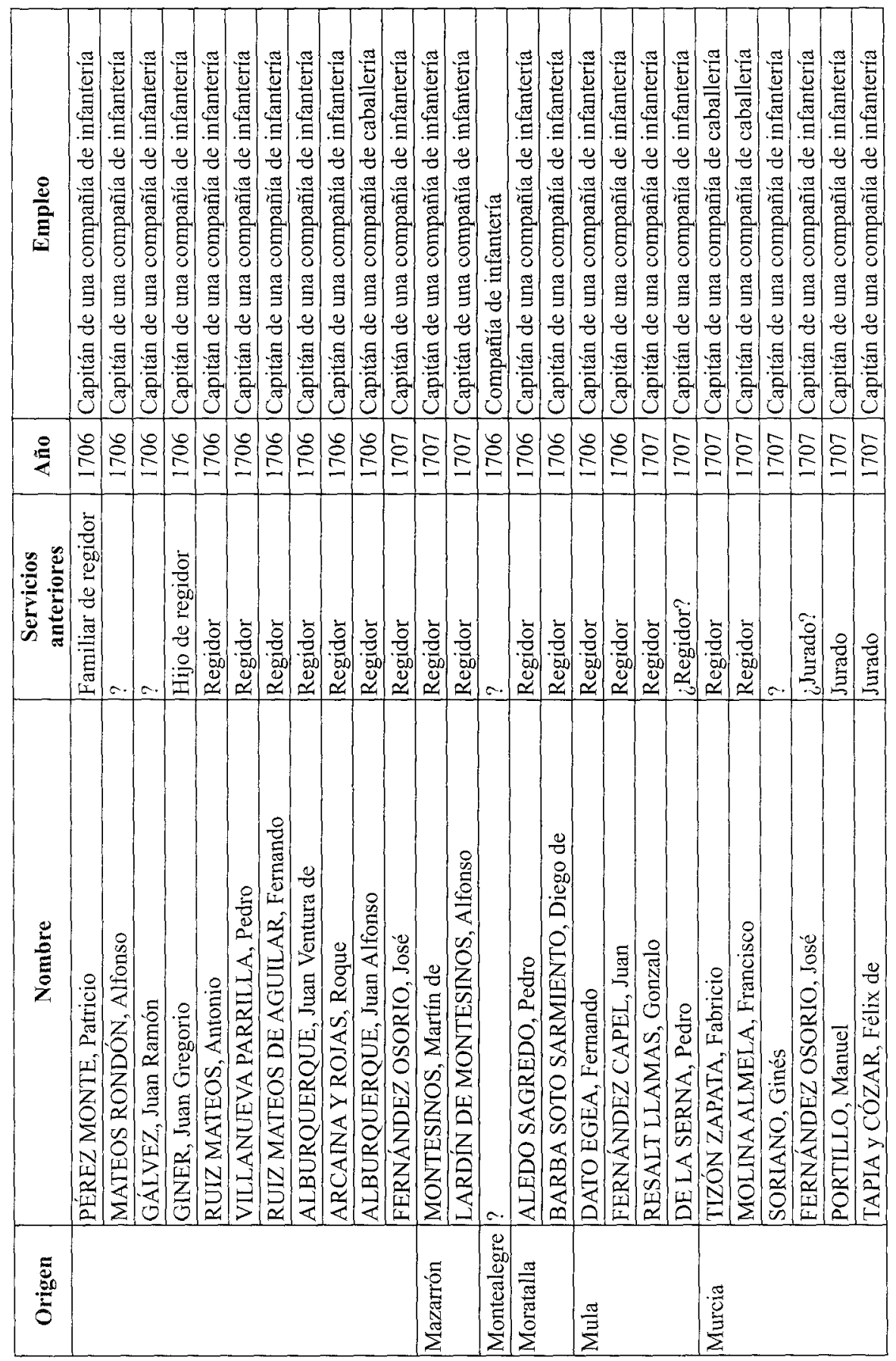




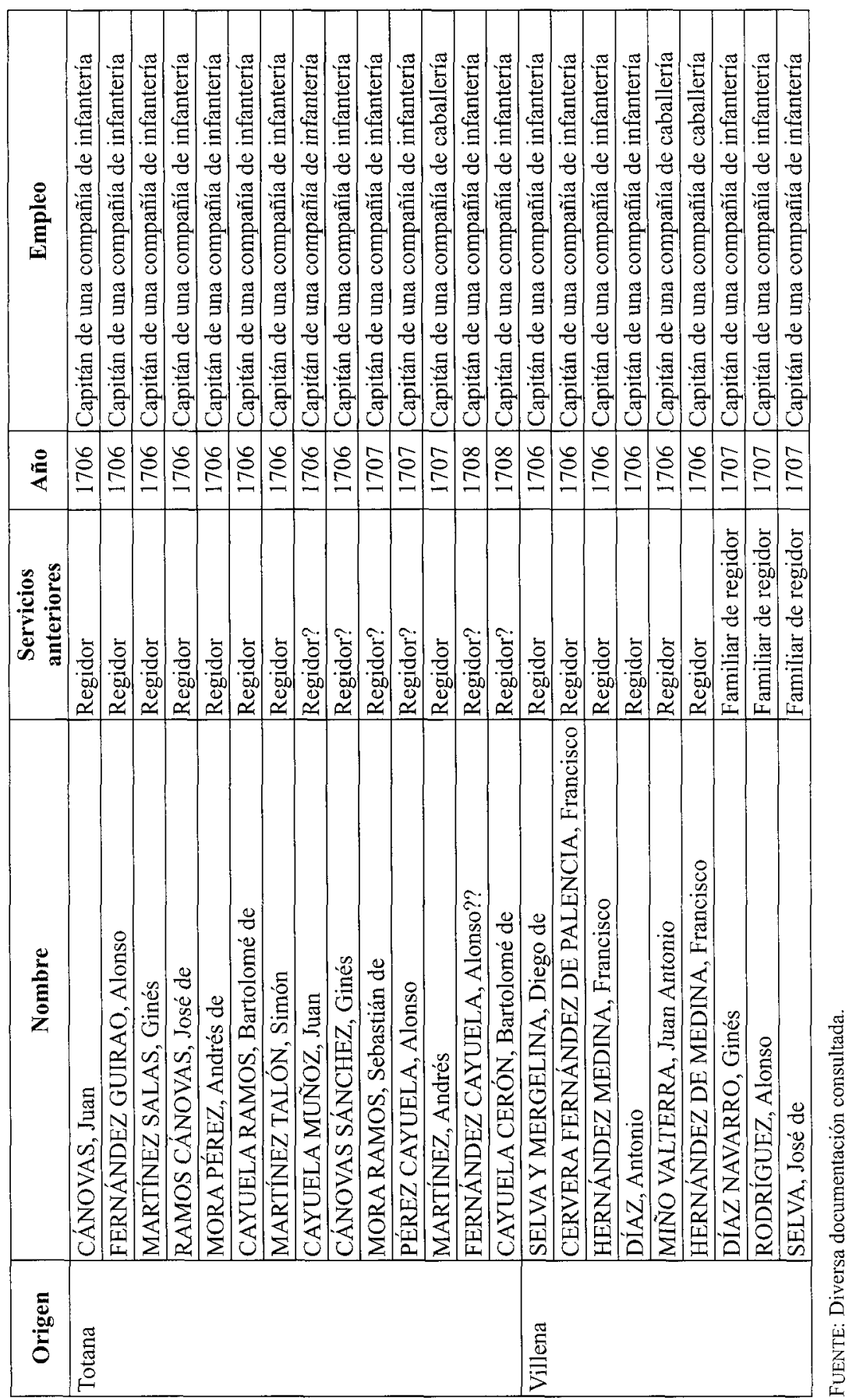

